\title{
How Does Environmental Interpretation Affect Psychological Well-Being? A Study Conducted in the Context of COVID-19
}

\author{
Hoang Viet Nguyen ${ }^{1, *}$, Wilson Dang ${ }^{2}$, Hoang Nguyen ${ }^{1}$, Thi Nguyen Hong Nguyen ${ }^{3}$, Thi My Nguyet Nguyen ${ }^{4}$, \\ Tuan Duong $\mathrm{Vu}^{4} \mathbb{1}^{-}$and Ninh Nguyen ${ }^{5,6}$
}

1 Board of Rectors, Thuongmai University, Hanoi 100000, Vietnam; nguyenhoang@tmu.edu.vn

2 Department of Business Administration, Dong Nai Technology University, Bien Hoa 810000, Vietnam; wilsondang76@gmail.com

3 Faculty of Hospitality-Tourism, Thuongmai University, Hanoi 100000, Vietnam; hongntn@tmu.edu.vn

4 Department of Strategic Management, Faculty of Business Administration, Thuongmai University, Hanoi 100000, Vietnam; mynguyet@tmu.edu.vn (T.M.N.N.); vutuanduong@tmu.edu.vn (T.D.V.)

5 Asia Pacific College of Business and Law, Charles Darwin University, Darwin City, NT 0800, Australia; ninh.nguyen@cdu.edu.au or ninhnguyen@tmu.edu.vn

6 Business Sustainability Research Group, Thuongmai University, Hanoi 100000, Vietnam

* Correspondence: nhviet@tmu.edu.vn; Tel.: +84-4-3764-3219

check for

updates

Citation: Nguyen, H.V.; Dang, W.; Nguyen, H.; Nguyen, T.N.H.;

Nguyen, T.M.N.; Vu, T.D.; Nguyen, N.

How Does Environmental

Interpretation Affect Psychological Well-Being? A Study Conducted in the Context of COVID-19.

Sustainability 2021, 13, 8522. https://

doi.org/10.3390/su13158522

Academic Editor: Serik Meirmanov

Received: 10 June 2021

Accepted: 27 July 2021

Published: 30 July 2021

Publisher's Note: MDPI stays neutral with regard to jurisdictional claims in published maps and institutional affiliations.

Copyright: (C) 2021 by the authors Licensee MDPI, Basel, Switzerland. This article is an open access article distributed under the terms and conditions of the Creative Commons Attribution (CC BY) license (https:// creativecommons.org/licenses/by/ $4.0 /)$.

\begin{abstract}
The COVID-19 crisis has challenged and generated severe impact on the global society, economy, and environment. Under this pandemic context, governments and organizations around the world have issued and strengthened environmental policies and regulations to protect the environment and human health. However, the extant knowledge about how people's interpretation of environmental policies and regulations influence their psychological well-being in the context of the COVID-19 pandemic is still limited. This study, therefore, investigates the impact of environmental interpretation on psychological well-being with the mediating role of environmentally responsible behavior and the moderating role of psychological contract violation. Using the data from a large sample of 960 residents in China, results of structural equation modeling show a positive relationship between environmental interpretation and psychological well-being, and this relationship is mediated by environmentally responsible behavior. Notably, psychological contract violation has a moderating effect on the indirect effect of environmental interpretation on psychological well-being via environmentally responsible behavior. These findings have several important implications for policymakers in environmental sustainability and pandemic planning.
\end{abstract}

Keywords: environmental interpretation; psychological well-being; environmentally responsible behavior; psychological contract violation; COVID-19

\section{Introduction}

Coronavirus (COVID-19) was first identified in late 2019 in the province of Wuhan in China. The WHO declared the outbreak of the pandemic in March 2020. More than 173 million cases of COVID-19 have been identified globally as of June 2021 [1]. The pandemic has engendered tremendous damage to the world. Specifically, global social and economic systems have been largely disrupted for a long time. Social media has reported that several events, e.g., sporting, religious, entertainment, and cultural events, have been canceled and postponed as a result of the pandemic. Business and education activities have also been seriously affected such that most universities and business firms have been closed in more than 172 countries [2]. The COVID-19 pandemic continues to be the largest threat and challenge for people around the world in 2021 [3,4].

Given the severity of the COVID-19 crisis, governments and organizations around the world have issued and strengthened regulations and restrictions with the hope to prevent and reduce the impact of the pandemic. Some notable initiatives include hand 
washing, surface cleaning, face masks, social distancing, self-isolation, travel restriction, public gathering restriction, and lockdown restriction [1]. These measures prevent not only the direct infection of humans by the virus but also its spread to the external environment (e.g., public areas). Furthermore, the COVID-19 pandemic has also generated impact on the environment and climate [5]. Therefore, additional programs and management guidelines have been developed and implemented to protect the ecosystem [6]. For example, The United Nations Environment Programme (UNEP) has launched several programs to help nations respond and manage the global environment. The Geneva Environment Network has also issued several guidelines to instruct individuals, business firms, and countries to deal with environmental problems during the pandemic.

During the pandemic period, human health and safety may be the main concern of most people. In addition, it can be argued that people are also concerned about environmental protection because they often perceive a close relationship between human health and the external environment. Several studies have explored the impact of COVID-19 on the environment [6-10]. Nevertheless, there is limited evidence about people's interpretations of environmental regulations, policies, and guidelines in COVID-19. Environmental interpretation refers to individuals' perceptions, interpretations, and understanding of environmental policy, regulation, legislation, and management system that are related to environmental protection [11]. Such an interpretation may be important in predicting people's willingness to engage in pro-environmental behavior and their overall well-being. However, to the best of the researchers' knowledge, no studies have comprehensively investigated how people's environmental interpretation influences their environmentally responsible behavior and psychological well-being.

A factor that may affect the relationships among environmental interpretation, proenvironmental behavior and psychological well-being is psychological contract violation. This concept refers to the perception of a psychological contract breach that leads to an emotional reaction, and the intensity of that reaction [12]. For example, when an individual perceives that other people violate environmental regulations (i.e., high level of psychological contract violation), they may behave in a similar manner, and their environmentally responsible behavior or psychological well-being will be less influenced by environmental interpretation. Therefore, investigation of the role of psychological contract violation would provide a comprehensive understanding of the mechanism through which people's perceptions of environmental policies impact their psychological well-being.

This research aims to contribute to the literature relating to environmentally sustainable behavior and psychological well-being in the context of a health crisis such as COVID-19. The research objectives are threefold:

(1) to investigate how people's interpretations of environmental regulations influence psychological well-being;

(2) to analyze the role of environmentally responsible behavior in the relationship between environmental interpretation and psychological well-being; and

(3) to examine whether and how psychological contract violation affects people's perceptions of environmental regulations and their environmentally responsible behavior.

To fulfil the above objectives, this study uses the data from a large sample of 960 residents in China to determine the relationship between environmental interpretation and psychological well-being with the mediating role of environmentally responsible behavior and the moderating role of psychological contract violation. China is selected as target of this study because it is known as the first place where the pandemic occurred, and it is also the country with largest population in the world. Due to the severity and wide spread of the pandemic in China, the country is facing a very high risk of infection of the virus. Under the context of the COVID-19 pandemic in China, it is meaningful to understand how Chinese people's perceptions and behavior toward environmental regulations influence their psychological well-being.

The structure of this study includes five sections. Section 2 reviews the literature and develops hypotheses, while Section 3 discusses the methodology including the data 
collection procedure and research ethics. Section 4 provides empirical results, and Section 5 discusses their implications. Section 6 is on conclusions and future research.

\section{Literature and Hypotheses}

\subsection{Psychological Well-Being}

Psychological well-being refers to an individual's overall well-being, which reflects the quality of their life as a whole [13]. Psychological well-being has been discussed and measured from different viewpoints. For example, social scientists have defined well-being in terms of what leads people to assess their lives in a positive way [14]. Diener [15] viewed well-being as pleasant emotional experiences and satisfaction with life. Lyubomirsky and Lepper [16] suggested that subjective happiness can be used to reflect psychological wellbeing, by measuring whether a person is happy or unhappy. In current literature, several studies have investigated antecedents of psychological well-being, including internet use [17], online communication technologies [18], subjective quality of leisure [19], social networking site use [20], cellphone use [21], social capital [22], and psychological need for online communication [23]. In this study, we adopt the concept of psychological well-being from Diener [15], which indicates an individual's subjective assessment of his or her overall satisfaction with social life.

\subsection{Environmental Interpetation and Psychological Well-Being}

Some research studies have examined the impact of the COVID-19 outbreak on the environment. Atalan [24] stated that the severity of the COVID-19 pandemic has led to lockdown, quarantine, and several restrictions globally. These policies have been viewed as effective ways to reduce the spread of the coronavirus and its impact on the global environment. Berman and Ebisu [7] examined air quality in the USA and reported a substantial reduction of $\mathrm{NO}_{2}$ and PM2.5 during the pandemic. Lah et al. [9] used satellite imagery and climatic datasets to determine the quality of the global environment during COVID-19 in India. The authors found a significant reduction in the level of $\mathrm{NO}_{2}, \mathrm{CO}$, and AOD, which is the result of the mass lockdown policy. Muhammad et al. [6] adopted NASA's and the European Space Agency's data and found that pollution in areas (e.g., Italy, Spain, USA, Wuhan) during COVID-19 has reduced up to $30 \%$. These studies have provided rich evidence for the effect of the COVID-19 pandemic on the environment.

He and Harris [8] suggested that the COVID-19 outbreak provides a great opportunity for companies to address global social and environmental challenges. Tosepu et al. [10] also stated that environmental policies and regulations help to manage and reduce climate change during the COVID-19 pandemic. Due to the rapid spread and severity of the disease, several environmental regulations have been announced and implemented around the world [1]. The purpose of these regulations is to reduce the impact of the virus on human health and other aspects of human life. On one hand, these regulations help to prevent the spread of the virus, thereby increasing people's psychological safety and feeling of security [25]. On the other hand, people may perceive, interpret, and understand environmental regulations that are executed by government agencies and publicized by social media. Under the context of COVID-19 pandemic, people may specially notice and comply with environmental regulations with a hope to prevent the spread of the disease [24]. Consequently, people may experience a positive emotion and feeling of satisfaction because they understand that environmental regulations help to protect and increase positive outcomes for human beings [26]. Therefore, it is expected that when people perceive, interpret, and understand environmental regulations, they will comply with these regulations. As a result, they may experience a feeling of satisfaction because of the positive outcomes of these environmental regulations. The following hypothesis is therefore suggested.

Hypothesis 1 (H1). Environmental interpretation is positively related to psychological well-being. 


\subsection{The Mediating Role of Environmentally Responsible Behaviour}

Environmentally responsible behavior is "any behavior an individual would undertake to conserve personal environments and/or solve environmental problems" [27] (p. 181). In other words, it reflects actions that individuals take to further the protection and conservation of the national environment [28]. Notably, environmentally responsible behavior refers to a person's willingness to engage in a specific behavior to protect the ecosystem [9], and this concept may include various activities such as recycling, education, persuasive action, and civic action [29]. In terms of consumer behavior, Thapa [30] suggested that environmentally responsible behavior comprises important activities such as purchasing behavior that minimizes environmental impacts, educating oneself about environmental concerns, recycling behavior, and influencing public environmental decisions.

Climate change and sustainable development have been important issues that focused people's attentions and concerns in the past decades [31]. With the explosion of the COVID19 pandemic, people tend to care more about the environment because they perceive the rapid spread and severity of the virus [7]. In this circumstance, people are more likely to notice and comply with environmental regulations announced by the governments [8]. In other words, the risk of the COVID-19 pandemic raises people' feeling of insecurity and psychological unsafety. To ensure safety and prevent viral infection, people tend to follow the instructions of environmental regulations. They also actively engage in activities that protect the environment. The reason is that people may believe their activities help to protect the environment, which will ensure safety for human health [25]. Furthermore, during the COVID-19 period, environmental protection activities help to prevent the spread of the disease. Such protection activities also reduce environmental pollution due to the reduction of $\mathrm{CO}_{2}$ and other wastes [6]. Consequently, people tend to experience positive emotions and a feeling of happiness because their environmentally responsible behavior helps to improve environmental problems, which contributes to the improvement of human health [26]. Therefore, it is expected that environmental interpretation during the COVID19 pandemic will motivate people to engage in environmentally responsible behavior, which in turn enhances psychological well-being. This suggests the following hypothesis.

Hypothesis 2 (H2). Environmentally responsible behavior positively mediates the relationship between environmental interpretation and psychological well-being.

\subsection{Psychological Contract Violation and Its Moderating Effect}

The concept of psychological contract violation, which is proposed by Morrison and Robinson [12], has been widely used in psychology and organization management literature. For example, a supervisor may promise his employee that he or she will be promoted in the next six months and yet this does not happen [32]. Psychological contract is not only a phenomenon between employer and employee or between employee and supervisor but also an essential relationship between buyer and seller in the business environment [33]. In a broader manner, Rousseau and Tijoriwala [34] referred to the psychological contract violation to as "an individual's belief in a breach of mutual obligations between that person and another party" (p. 679). In other words, one party may believe that another party violates the promise of reciprocal exchange and that he or she does not perform certain behavior to fulfill his or her obligations in the exchange [35].

Malhotra et al. [33] stressed that psychological contract violation is a common phenomenon between people in society. In a public area, people often perceive and comply with laws and regulations issued by government agencies. Naturally, people form a psychological contract with the government to control and regulate their behavior [36]. For example, people comply with traffic rules when they go out on the streets. Similarly, people also observe other people and modify their behavior in the public areas [37]. For example, when an individual sees other people recycling waste and keeping the public area clean, they may also engage in recycling behavior. By contrast, if an individual perceives that nobody recycles and throw rubbish in public areas, they may do the same thing. That 
is, people form a psychological contract to behave and modify their behavior in public areas. People may violate such a psychological contract when they perceive other people breaching their obligations [38].

Several studies have indicated the negative impact of psychological contract violation. Arasli et al. [39] found that when employees perceived a violation of a psychological contract, they tended to hold a high intention of turnover. Duran et al. [40] demonstrated that psychological contract violation negatively affects psychological well-being. Hammer et al. [41] indicated that people tend to stop sharing their information and knowledge on social media when they perceive other people violating the psychological contract. Malhotra et al. [33] reported that psychological contract violation destroys trust and satisfaction in buyer-seller relationships. Peng et al. [38] found negative associations between psychological contract violation and employees' behaviors. In the context of public areas, people often form a psychological contract with other individuals in society (e.g., when people participate in social activities). They often observe and behave in ways that are consistent with other people in society [42]. For example, people observe others' behavior to decide their investment in stock market [43] or to choose restaurants [42] and buy homes [44].

Similarly, psychological contract violation may influence people's perceptions and behavior regarding environmental behavior. In an extreme case such as COVID-19, if an individual perceives that everyone in society violates environmental regulations (e.g., does not wear masks and wash hands or does not comply with the lockdown regulations during COVID-19, etc.), they may behave in the same ways, and their environmentally responsible behavior may be less affected by their environmental interpretation. That is, a high level of psychological contract violation may weaken people's perceptions and responses toward environmentally irresponsible behavior. In contrast, when an individual observes that other people comply with environmental regulations (i.e., low level of psychological contract violation), they may obey the regulations and actively engage in environmentally responsible behavior. Therefore, it is expected that the relationship between environmental interpretation and environmentally responsible behavior will vary with different levels of psychological contraction violation between people in society. The following hypothesis is then developed.

Hypothesis 3 (H3). Psychological contract violation moderates the association between environmental interpretation and environmentally responsible behavior, such that the association is strengthened when psychological contract violation is low and weakened when psychological contract violation is high.

Figure 1 illustrates the research model including the aforementioned hypotheses.

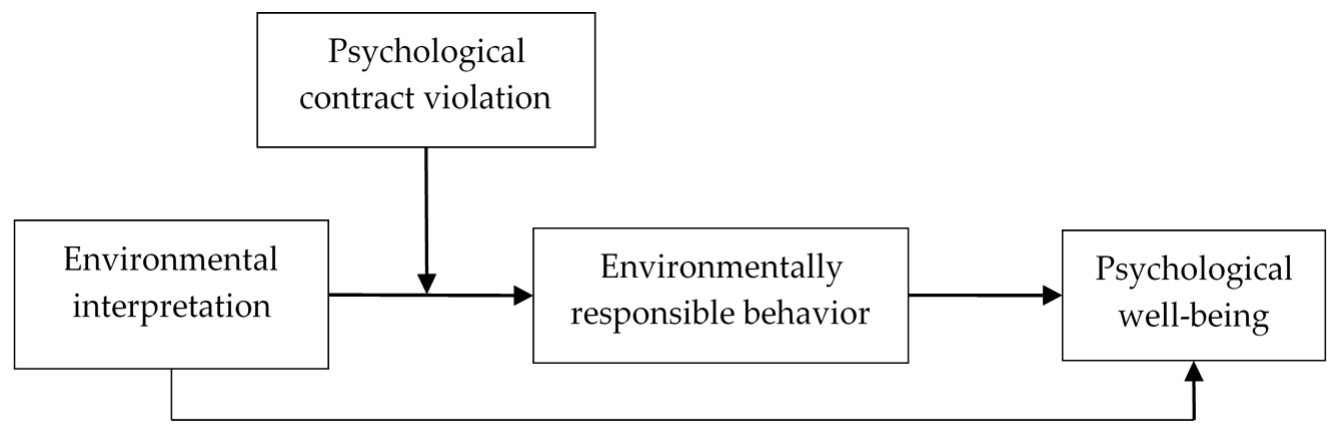

Figure 1. The research model. 


\section{Method}

\subsection{Questionnaire Design}

This research measures all variables using measurement scales from prior studies. Specifically, the measures of environmental interpretation were adopted from Lin [45] with four items. The measures of environmentally responsible behavior were adopted from Cheng et al. [46] with six items. The measures of psychological contract violation were adopted from Robinson and Morrison [32] with four items. The measures of psychological well-being were adopted from Diener [15] with four items. Details of the measurement items are presented in Table 1 . The measures of all variables were assessed using a fivepoint Likert-type agreement scale.

Table 1. Constructs and items.

\begin{tabular}{|c|c|c|}
\hline Constructs & Items & References \\
\hline \multirow{4}{*}{$\begin{array}{l}\text { Environmental } \\
\text { interpretation (EI) }\end{array}$} & EI1. Environmental warning makes me regulate my environmental behaviors consciously. & \multirow{4}{*}{ [45] } \\
\hline & $\begin{array}{c}\text { EI2. Environmental protection policies make me regulate my environmental } \\
\text { behaviors consciously. }\end{array}$ & \\
\hline & $\begin{array}{l}\text { EI3. Rewards and punitive measures for environmental protection make me regulate my } \\
\text { environmental behaviors consciously. }\end{array}$ & \\
\hline & $\begin{array}{l}\text { EI4. Persuasive environment friendly signages in public areas make me regulate my } \\
\text { environmental behaviors consciously. }\end{array}$ & \\
\hline \multirow{6}{*}{$\begin{array}{l}\text { Environmentally } \\
\text { responsible } \\
\text { behavior (ERB) }\end{array}$} & ERB1. I follow the legal ways to stop the destruction of the environment. & \multirow{6}{*}{ [46] } \\
\hline & $\begin{array}{l}\text { ERB2. When I see others engaged in the destruction of the environment, I will report it to the } \\
\text { administration units. }\end{array}$ & \\
\hline & $\begin{array}{l}\text { ERB3. When I see garbage and tree branches on the ground, I will pick them up and put them } \\
\text { in the trash. }\end{array}$ & \\
\hline & ERB4. If there are environmental clean-up activities, I would be willing to attend. & \\
\hline & ERB5. I try to convince others to protect the natural environment. & \\
\hline & ERB6. I try not to disrupt the fauna and flora in the area where I live. & \\
\hline \multirow{4}{*}{$\begin{array}{c}\text { Psychological } \\
\text { contract violation } \\
(\mathrm{PCV})\end{array}$} & PCV1. I feel a great deal of anger toward other people in society. & \multirow{4}{*}{ [32] } \\
\hline & PCV2. I feel betrayed by other people in society. & \\
\hline & PCV3. I feel that other people have violated the social norms. & \\
\hline & PCV4. I feel extremely frustrated by how I have been treated by other people in society. & \\
\hline \multirow{4}{*}{$\begin{array}{l}\text { Psychological } \\
\text { well-being (PW) }\end{array}$} & PW1. In most ways, my social life is close to my ideal. & \multirow{4}{*}{ [15] } \\
\hline & PW2. I am satisfied with my social life. & \\
\hline & PW3. So far, I have got the important things I want in my social life. & \\
\hline & PW4. If I could live my social life again, I would change almost nothing. & \\
\hline
\end{tabular}

Prior to data collection, this study conducted a two-stage pilot test. Initially, four professors in the fields of management and sustainability were invited to assess the content validity and quality of the measures. The questionnaire containing the measures was then administered to 30 respondents, who were asked to comment on the clarity of the items and the layout of the questionnaire. Following the pilot test, minor amendments were made to the wording and structure of the questionnaire.

\subsection{Data Collection}

This study recruited a research assistant team with six members who had considerable experience in consumer data collection. The team delivered questionnaire to residents in Guangzhou city in China. Guangzhou was chosen because it is the third-largest city in China with more than 15 million people. The city is one of the areas that face a high risk 
of the viral infection during the ongoing COVID-19 pandemic. Environmental protection and sustainable development have become an extremely important issue for the city during the last few years. From the 1000 residents who voluntarily participated the survey, 966 questionnaires were returned, and 960 completed questionnaires were included in the final data analysis. The response rate of the survey is $96 \%$ and only six questionnaires were invalid due to missing data.

\subsection{Reseach Ethics}

This study collected data relevant to human activity. To address ethical standards, the study was conducted in accordance with "the guidelines of the Declaration of Helsinki". In addition, the research protocol was reviewed and approved by the Department of Research Administration at Thuongmai University (DRA-2020-2). Privacy and negative impact have been carefully considered during the survey procedure. The questionnaire was anonymous, and participants voluntarily participated in the survey. Importantly, all participants were asked to read the cover page of the questionnaire, which includes the research objectives and an informed consent statement. Furthermore, the research assistants verbally explained the consent information to the participants and emphasized that completion of the questionnaire was taken as their "informed consent" to participate in this research.

\subsection{Analytical Method}

This study used both SPSS 24.0 and AMOS 24.0 (IBM, Endicott, NY, USA) to analyze sample data. The descriptive statistics and reliability were analyzed using the SPSS statistical software. The validity and hypotheses were examined using structural equation modeling (SEM). Specifically, the AMOS software was applied to generate a measurement model and a structural model that helped to assess the goodness of fit and validity and test the hypotheses.

\section{Method}

\subsection{Descriptive Statistical Analysis of the Sample}

The characteristics of the respondents in this study are presented in Table 2. The proportion of females (622 participants, $64.8 \%$ ) was higher than that of males (338 participants, $35.2 \%$ ). Most respondents were aged between 20 and $<30$ (573 participants, 59.7\%), about 182 participants (19.0\%) were aged under 20, 139 participants $(14.5 \%)$ were aged between 30 and $<40$, and only 66 participants $(6.9 \%)$ were aged 41 or above. Furthermore, approximately 675 respondents $(70.3 \%)$ had university education, 258 respondents $(26.9 \%)$ had high school or below education, and only 27 respondents $(2.8 \%)$ had master's or above education. About 632 respondents (65.8\%) had income between USD 500 and $<$ USD 1000, 248 respondents $(25.8 \%)$ had income under USD 500, and only 80 respondents $(8.3 \%)$ had an income of USD 1000 or above.

Table 2. Sample demographics.

\begin{tabular}{ccc}
\hline Variables & Frequency & Percent \\
\hline Gender & 338 & \\
Male & 622 & 35.2 \\
Female & & 64.8 \\
Age & 182 & \\
Under 20 & 573 & $19.00 \%$ \\
20 to $<30$ & 139 & $59.70 \%$ \\
30 to $<40$ & 66 & $14.50 \%$ \\
41 and above & & $6.90 \%$ \\
Education & 258 & \\
High school and below & 675 & $26.90 \%$ \\
University & 27 & $70.30 \%$ \\
Master and above & & $2.80 \%$ \\
\hline
\end{tabular}


Table 2. Cont.

\begin{tabular}{ccc}
\hline Variables & Frequency & Percent \\
\hline Income & & \\
Under USD 500 & 248 & $25.80 \%$ \\
USD 500 to <USD 1000 & 632 & $65.80 \%$ \\
USD 1000 or above & 80 & $8.30 \%$ \\
e & & \\
\hline Note: $n=960$. & &
\end{tabular}

\subsection{Reliability and Validity}

Cronbach's $\alpha$, which must be greater than 0.60 , is often used to measure the reliability of the measurement scales [47]. Results in Table 3 reveal that Cronbach's $\alpha$ for the constructs lay between 0.77 and 0.93 , indicating a good reliability of the measures in this study.

Table 3. Reliability and convergent validity.

\begin{tabular}{cccccc}
\hline Construct & Item & Loadings & CR & AVE & Cronbach's $\alpha$ \\
\hline \multirow{2}{*}{ Environmental } & EI1 & $0.87^{* * * *}$ & & & \\
interpretation & EI2 & $0.83^{* * *}$ & 0.93 & 0.76 & 0.93 \\
& EI3 & $0.89^{* * *}$ & & & \\
& EI4 & $0.89^{* * *}$ & & & \\
Environmentally & ERB2 & $0.86^{* * *}$ & & & \\
EResponsible behavior & ERB3 & $0.86^{* * *}$ & & & \\
& ERB4 & $0.83^{* * *}$ & \multirow{2}{*}{0.93} & 0.68 & \\
& ERB5 & $0.83^{* * *}$ & & & \\
ERB6 & $0.77^{* * *}$ & & & \\
Psychological contract & PCV1 & $0.84^{* * *}$ & & & \\
violation & PCV2 & $0.88^{* * *}$ & & & \\
& PCV3 & $0.79^{* * *}$ & 0.84 & 0.59 & \\
PSychological & PCV & $0.50^{* * *}$ & & & \\
well-being & PW2 & $0.52^{* * *}$ & & & \\
& PW3 & $0.84^{* * *}$ & & & \\
& PW4 & $0.85^{* * *}$ & 0.86 & 0.61 & \\
\hline
\end{tabular}

Note: $n=960,{ }^{* * *} p<0.001$.

To test the validity of the measures, this study conducted a measurement model using AMOS 24.0. Results of this model indicate that chi-square/degree of freedom $=356.655 / 123=2.90$, $\mathrm{CFI}=0.95, \mathrm{GFI}=0.92, \mathrm{TLI}=0.94$, and $\mathrm{RMSEA}=0.07$. These values met the requirements for a good model fit (chi-square/degree of freedom must be less than 3; CFI, GFI, and TLI must be greater than 0.90; and RMSEA must be less than 0.08) [48]. Results from this measurement model enable the calculation of "composite reliability" (CR) and "average variance extracted" (AVE), which were used to test the convergent validity of the measures. Hair et al. [47] suggested that CR must be higher than 0.70 and AVE must exceed 0.50. Results in Table 3 confirm good convergent validity of this study's measures (CR values ranged from 0.83 to 0.93 , AVE values ranged from 0.59 to 0.76 ).

Discriminant validity of the measures was tested by comparing the values of square roots of AVE and the bivariate correlation coefficients of variables [47]. According to Table 4, the square roots of AVE exceed all correlation coefficient values. This confirms good discriminant validity of the study's measures. 
Table 4. Pearson correlation and discriminant validity.

\begin{tabular}{ccccccc}
\hline Construct & Mean & SD & $\mathbf{1}$ & $\mathbf{2}$ & $\mathbf{3}$ & $\mathbf{4}$ \\
\hline 1. Environmetal interpretation & 3.64 & 0.83 & 0.87 & & & \\
2. Environmentally responsible behavior & 3.78 & 0.79 & $0.44^{* *}$ & 0.83 & & \\
3. Psychological contract violation & 3.61 & 0.84 & $0.46^{* *}$ & $0.48^{* *}$ & 0.77 & $0.41^{* *}$ \\
4. Psychological well-being & 3.58 & 0.80 & $0.35^{* *}$ & $0.49^{* *}$ & 0.78 \\
\hline
\end{tabular}

Note: $n=960,{ }^{* *} p<0.01$, square roots of AVE are on the diagonal.

\subsection{Common Method Bias}

This study examined common method bias using suggestions from Podsakoff et al. [49]. Results of Harman's one factor test show that four factors emerged with $68.60 \%$ of variance, and the first factor accounted only for $21.75 \%$ of variance. The results of one-factor model of confirmatory factor analysis provide further evidence with a very poor model fit (chi-square $/$ degree of freedom $=3349.22 / 119=28.14, \mathrm{CFI}=0.73, \mathrm{GFI}=0.63, \mathrm{TLI}=0.69$, RMSEA = 0.17). Thus, it is reasonable to conclude that common method bias should not be a serious problem and may not seriously affect the hypothesis testing.

\subsection{Hypothesis Testing}

Results of hypothesis testing are shown in Figure 2. Results indicate that environmental interpretation had a positive influence on psychological well-being $(\beta=0.384, p<0.001)$. Thus, hypothesis H1 was supported.

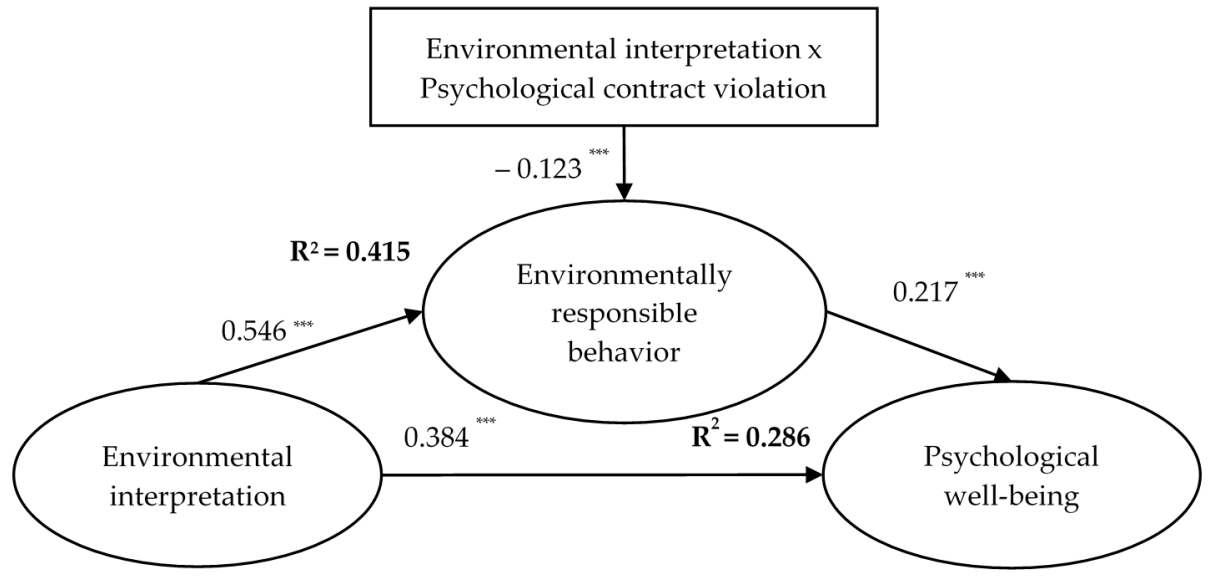

Note: ${ }^{* * *} p<0.001$

Figure 2. Results of hypothesis testing.

Furthermore, environmental interpretation had a positive impact on environmentally responsible behavior $(\beta=0.546, p<0.001)$, which successively exerted a positive impact on psychological well-being $(\beta=0.217, p<0.001)$. To confirm this indirect effect, this study used Preacher et al.'s [50] method of 1000 bootstrap samples. Results show that the indirect effect of environmental interpretation on psychological well-being via environmentally responsible behavior was statistically significant $(\beta=0.154, p<0.0195 \% \mathrm{CI}=[0.091,0.219])$, providing support for hypothesis $\mathrm{H} 2$.

Results in Figure 2 show that the interaction effect between environmental interpretation and psychological contract violation was negatively related to environmentally responsible behavior $(\beta=-0.123, p<0.001)$. Furthermore, Figure 3 indicates that the influence of environmental interpretation on environmentally responsible behavior was weaker when psychological contract violation was high and stronger when psychological contract violation was low. Thus, hypothesis H3 was supported, confirming that the increase in psychological contract violation weakened the environmental interpretation-environmental responsibility relationship. There are two possible explanations for this moderation. First, 
when a person observes that others severely violated social norms and environmental regulations (i.e., high level of psychological contract violation), they may behave in the same ways and be less concerned about environmental regulations and behaviors. Second, the person may doubt the quality and effectiveness of these environmental regulations. This consequently reduces the person's environmental interpretation and its impact on their environmentally responsible behavior.

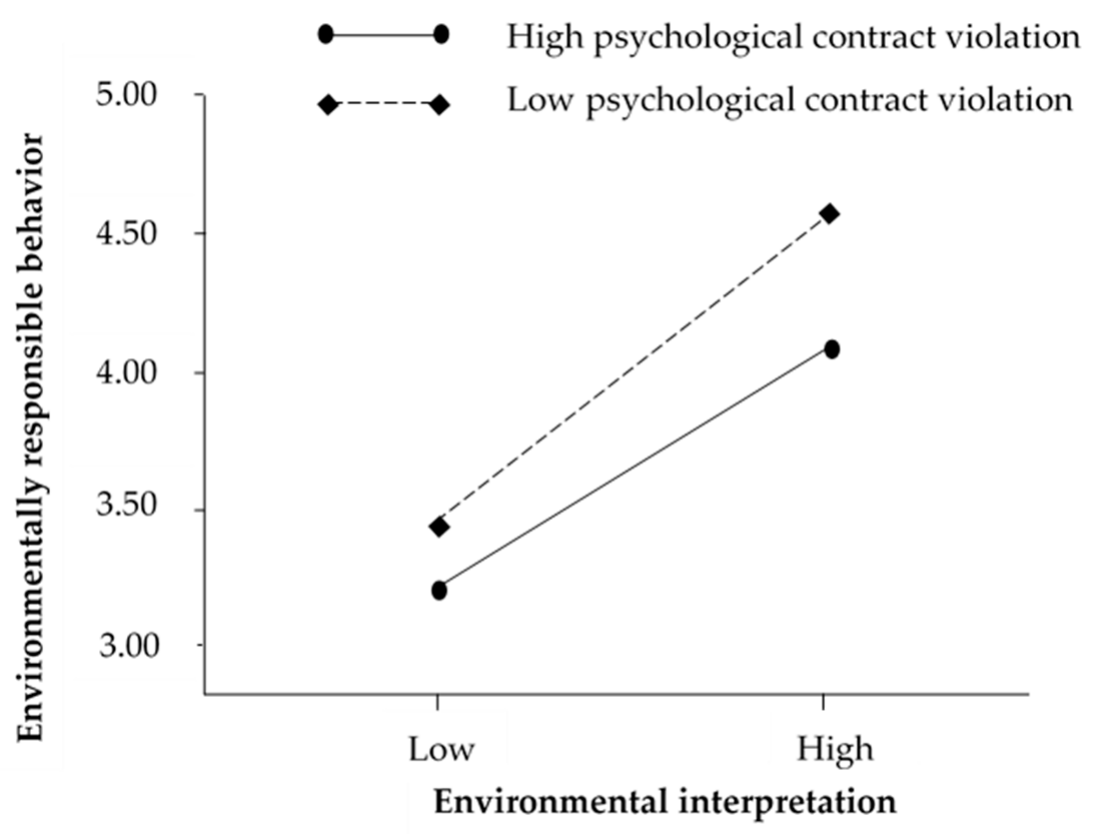

Figure 3. Interactive effect of environmental interpretation and psychological contract violation on environmentally responsible behavior.

Given that $\mathrm{H} 2$ and $\mathrm{H} 3$ were supported, further analysis was conducted to examine whether psychological contract violation would moderate the indirect influence of environmental interpretation on psychological well-being through environmentally responsible behavior. As indicated in Table 5, the indirect influence of environmental interpretation on psychological well-being via environmentally responsible behavior varied between "high psychological contract violation" and "low psychological contract violation" ( $\triangle \beta=0.092$, $p<0.001)$. In other words, the indirect influence of environmental interpretation on psychological well-being via environmentally responsible behavior was stronger when psychological contract violation was low $(\beta=0.146, p<0.001)$ and weaker when psychological contract violation was high $(\beta=0.054, p<0.001)$. Thus, psychological contract violation played a moderating role in the indirection relationship between environmental interpretation and psychological well-being.

Table 5. Further analysis of the moderating role of psychological contract violation.

\begin{tabular}{|c|c|c|c|c|c|}
\hline \multirow{4}{*}{ Moderator } & \multicolumn{5}{|c|}{ Environmental Interpretation $(\mathrm{X}) \rightarrow$ Environmentally Responsible Behavior $(\mathrm{M}) \rightarrow$ Psychological Well-Being $(\mathrm{Y})$} \\
\hline & \multicolumn{5}{|c|}{ Stage } \\
\hline & \multicolumn{2}{|c|}{$\begin{array}{l}\text { Stage } 1 \\
\left(P_{X \rightarrow M}\right)\end{array}$} & \multicolumn{3}{|c|}{ Effect } \\
\hline & $0.548 * * *$ & $\begin{array}{l}\text { Stage } 2 \\
\left(P_{M->Y}\right)\end{array}$ & $\begin{array}{c}\text { Direct Effects } \\
\left(\mathbf{P}_{\mathbf{X}->}\right)\end{array}$ & $\begin{array}{c}\text { Indirect Effects } \\
\left(\mathbf{P}_{X->M} \mathbf{P}_{M->Y}\right)\end{array}$ & $\begin{array}{c}\text { Total Effects } \\
\left(\mathbf{P}_{\mathrm{X}-\mathrm{Y}}+\mathbf{P}_{\mathrm{X}->\mathrm{M}} \mathbf{P}_{\mathrm{M}->\mathrm{Y}}\right)\end{array}$ \\
\hline High PCV & $0.632 * * *$ & $0.098 *$ & $0.311^{* * *}$ & $0.054 * * *$ & $0.365 * *$ \\
\hline Low PCV & $0.084^{* * *}$ & $0.231^{* * *}$ & $0.320 * * *$ & $0.146^{* * *}$ & 0.466 ** \\
\hline Differences & $0.084^{* * *}$ & $0.133^{* * *}$ & 0.009 & $0.092^{* * *}$ & $0.101 * *$ \\
\hline
\end{tabular}

Note: $n=960,{ }^{*} p<0.05,{ }^{* *} p<0.01,{ }^{* * *} p<0.001 ; \mathrm{PCV}=$ psychological contract violation. 


\section{Discussion and Implications}

This study aims at investigating the relationship between environmental interpretation and psychological well-being with the mediating role of environmentally responsible behavior and the moderating role of psychological contract violation. The study's findings have some theoretical and practical implications.

\subsection{Theoretical Implications}

First, research has mainly focused on the impact of the COVID-19 pandemic on human health and safety in the current period [24]. Although some studies have also investigated the impact of the COVID-19 pandemic on the environment and climate [7], little attention has been focused on the influence of people's perceptions about environmental regulations on their psychological well-being during the COVID-19 pandemic. The current study has filled this research gap and found that environmental interpretation had a positive impact on psychological well-being. This finding demonstrates that people are more likely to notice, interpret, and understand environmental policies and regulations during the COVID-19 pandemic. This may be because people perceive the severity and widespread nature of the pandemic [25]. Such a perception makes people relate environmental protection with prevention of the disease. That is, people may believe that environmental policies and regulations will contribute to the protection the environment and human health [26]. The findings of this study shed a new light on the influence of environmental interpretation on psychological well-being during the COVID-19 pandemic.

Second, prior studies have often focused on the antecedents of environmentally responsible behavior [31]. Very few studies have treated environmental responsible behavior as a mediating variable. In this study, we found that environmentally responsible behavior has a mediating effect in the association between environmental interpretation and psychological well-being. This finding implies that when people perceive and interpret environmental policies and regulations during the COVID-19 pandemic, they are more likely to engage in environmentally responsible behavior [7]. The reason is that when people understand the severity and seriousness of the pandemic, they tend to comply with environmental regulations and restrictions to protect the environment, and such behavior may help to prevent and reduce the spread of the virus [6,8]. Consequently, people may feel more safety and satisfied with their lives because their environmentally responsible behavior helps to protect human health from environmental pollution and the viral pandemic $[25,26]$. Therefore, the current study's findings provide fresh insights into the mediating mechanism of environmentally responsible behavior in the link between environmental interpretation and psychological well-being. These findings provide implications for researchers who will study the issue of environmentally responsible behavior during the COVID-19 pandemic.

Third, people often form a psychological contract with each other in society [33]. For example, the psychological contract between employers and employees, between supervisors and employees, or between sellers and buyers [34]. When people perceive that their psychological contract is violated, they tend to hold negative attitudes and behave in a negative way [40]. That is, psychological contract violation often generates negative outcomes [39]. Although psychological contract violation has been a focus of research in psychology and organization management literature, very few studies have considered the role of psychological contract violation between people in society in the context of environmental protection. This study has filled this research gap and found that psychological contract violation negatively moderated the link between environmental interpretation and environmentally responsible behavior. Furthermore, psychological contract violation also moderated the indirect effect of environmental interpretation on psychological well-being through environmentally responsible behavior. These findings indicate that when people notice other people in society violating a psychological contract (e.g., other people do not recycle waste, damage the environment, or do not comply with environmental policies and regulations during the COVID-19 pandemic), they also tend to do the same things 
and do not engage in environmentally responsible behavior $[37,38]$. Therefore, findings of this study clarify the moderating mechanism of psychological contract violation. These findings may provide implications for scholars who want to study the role of psychological contract in environmental protection issues.

Finally, this study proposes a unique model as the direct influence of environmental interpretation on psychological well-being has not been determined in current literature. Furthermore, the mediating mechanism of environmentally responsible behavior and the moderating mechanism of psychological contract violation have also been absent in prior studies. Thus, the unique model of this study provides a comprehensive picture to advance our knowledge about the effect of people's perceptions and behavior toward environmental protection on psychological well-being during the COVID-19 pandemic. Specifically, the context of this study is China where COVID-19 occurred at the first moment of the pandemic. Findings of this study may also provide implications for researchers who will study the issue of environmentally responsible behavior in China.

\subsection{Practical Impliations}

This study's findings also offer implications for practitioners at both macro and micro levels. At the macro level, it is suggested that government agencies should plan and execute several environmental policies and regulations to guide residents' behavior toward protection of the environment during the COVID-19 pandemic. Specifically, government agencies should use different social media to deliver and explain their environmental policies and regulations. These policies and regulations will motivate residents to actively engage in environmentally responsible behavior. As a result, residents will experience a higher psychological well-being because they contribute to the protection of environment and human health.

At the micro level, it is suggested that individual residents should pay attention and understand environmental policies and regulations issued by governments during the COVID-19 pandemic. Individual residents should also comply with these regulations and engage in environmentally responsible behavior. Their perceptions and behavior will help to protect the environment and increase their psychological well-being during the COVID-19 pandemic.

\section{Conclusions and Future Research}

This study, to the best of the researcher's knowledge, is the first attempt to examine the relationship between environmental interpretation and psychological well-being in the context of the COVID-19 pandemic, with the mediating role of environmentally responsible behavior and the moderating role of psychological contract violation. Several interesting results have been found in this study. First, environmental interpretation had a positive impact on psychological well-being. Second, environmentally responsible behavior was found to mediate the link between environmental interpretation and psychological well-being. Third, psychological contract violation had a moderating effect on the relationship between environmental interpretation and environmentally responsible behavior. Finally, psychological contract violation had a moderating effect on the indirect effect of environmental interpretation on psychological well-being via environmentally responsible behavior.

The current research, however, has several limitations that should be addressed in future studies. The disadvantage of cross-sectional data lies in its ability to reflect the causal relationships between variables. To overcome this limitation of cross-sectional data, it is suggested that future research should collect data at different points in time to validate the causal relationship between variables in this study. Furthermore, survey questionnaires often suffer from common variance bias because data are collected from respondents for all variables at the same time. This bias may distort the results of hypothesis testing in this study. Therefore, it is suggested that future research should use different methods to collect data and avoid the problem of common variance bias. In addition, several important variables have not been considered in our model. For example, people's perceptions of 
environmental change, the perceived severity of the COVID-19 pandemic, psychological safety, psychological depression, etc. Future researchers should examine these variables when they study the issue of environmental protection and psychological well-being during the pandemic.

Author Contributions: Conceptualization, H.V.N., W.D., H.N., T.N.H.N., T.M.N.N., T.D.V., and N.N.; methodology, H.V.N., W.D., H.N., T.N.H.N., T.M.N.N., and T.D.V.; formal analysis, H.V.N., W.D., T.M.N.N., and T.D.V.; writing—original draft preparation, H.V.N., W.D., H.N., T.N.H.N., T.M.N.N., T.D.V., and N.N.; writing-review and editing, H.V.N., W.D., H.N., T.N.H.N., T.M.N.N., T.D.V., and N.N. All authors have read and agreed to the published version of the manuscript.

Funding: This research received no external funding.

Institutional Review Board Statement: The study was conducted according to the guidelines of the Declaration of Helsinki and the research policies of the researchers' affiliations.

Informed Consent Statement: Informed consent was obtained from all subjects involved in the study.

Data Availability Statement: The data presented in this study are available on request from the corresponding author.

Acknowledgments: The researchers sincerely thank Van Thac Dang (Shantou Business School, Shantou University, China) and the research assistants for their invaluable support during the research design and data collection.

Conflicts of Interest: The authors declare no conflict of interest.

\section{References}

1. World Health Organization. International Health Regulations. 2021. Available online: https://www.who.int/ (accessed on 8 June 2021).

2. UNESCO. COVID-19 Response. 2020. Available online: https://en.unesco.org/covid19 (accessed on 8 June 2021).

3. Nguyen, H.; Nguyen, H.V.; Le, N.B.; Pham, T.T.T.; Nguyen, N. Online book fairs during the COVID-19 pandemic. Logos 2021, 32 , 37-43. [CrossRef]

4. Do, B.; Nguyen, N.; D'Souza, C.; Bui, H.D.; Nguyen, T.N.H. Strategic responses to COVID-19: The case of tour operators in Vietnam. Tour. Hosp. Res. 2021, in press. [CrossRef]

5. Marshall, B. COVID-19 reduces economic activity, which reduces pollution, which saves lives. Global Food, Environment and Economic Dynamics. 2020. Available online: http://www.g-feed.com/2020/03/covid-19-reduces-economic-activity.html (accessed on 11 May 2021).

6. Muhammad, S.; Long, X.; Salman, M. COVID-19 pandemic and environmental pollution: A blessing in disguise? Sci. Total Environ. 2020, 728, 138820. [CrossRef] [PubMed]

7. Berman, J.D.; Ebisu, K. Changes in US air pollution during the COVID-19 pandemic. Sci. Total Environ. 2020, $739,139864$. [CrossRef]

8. He, H.; Harris, L. The Impact of Covid-19 Pandemic on Corporate Social Responsibility and Marketing Philosophy. J. Bus. Res. 2020, 116, 176-182. [CrossRef] [PubMed]

9. Lal, P.; Kumar, A.; Kumar, S.; Kumari, S.; Saikia, P.; Dayanandan, A.; Adhikari, D.; Khan, M.L. The dark cloud with a silver lining: Assessing the impact of the SARS COVID-19 pandemic on the global environment. Sci. Total Environ. 2020, $732,139297$. [CrossRef] [PubMed]

10. Tosepu, R.; Gunawan, J.; Effendy, D.S.; Lestari, H.; Bahar, H.; Asfian, P. Correlation between weather and Covid-19 pandemic in Jakarta, Indonesia. Sci. Total Environ. 2020, 725, 138436. [CrossRef] [PubMed]

11. Wang, C.; Zhang, J.; Yu, P.; Hu, H. The theory of planned behavior as a model for understanding tourists' responsible environmental behaviors: The moderating role of environmental interpretations. J. Clean. Prod. 2018, 194, 425-434. [CrossRef]

12. Morrison, E.W.; Robinson, S.L. When employees feel betrayed: A model of how psychological contract violation develops. Acad. Manag. Rev. 1997, 22, 226-256. [CrossRef]

13. Hall, A. Making good choices: Toward a theory of well-being in medicine. Theor. Med. Bioeth. 2016, 37, 383-400. [CrossRef]

14. Ryff, C.D. Happiness is everything, or is it? Explorations on the meaning of psychological well-being. J. Personal. Soc. Psychol. 1989, 57, 1069. [CrossRef]

15. Diener, E. Subjective well-being. Psychol. Bull. 1984, 95, 542-575. [CrossRef] [PubMed]

16. Lyubomirsky, S.; Lepper, H.S. A measure of subjective happiness: Preliminary reliability and construct validation. Soc. Indic. Res. 1999, 46, 137-155. [CrossRef]

17. Castellacci, F.; Tveito, V. Internet use and well-being: A survey and a theoretical framework. Res. Policy 2018, 47, 308-325. [CrossRef] 
18. Ishii, K. Online communication with strong ties and subjective well-being in Japan. Comput. Hum. Behav. 2017, 66, 129-137. [CrossRef]

19. Kuykendall, L.; Lei, X.; Tay, L.; Cheung, H.K.; Kolze, M.; Lindsey, A.; Silvers, M.; Engelsted, L. Subjective quality of leisure \& worker well-being: Validating measures \& testing theory. J. Vocat. Behav. 2017, 103, 14-40.

20. Chen, W.; Fan, C.Y.; Liu, Q.X.; Zhou, Z.K.; Xie, X.C. Passive social network site use and subjective well-being: A moderated mediation model. Comput. Hum. Behav. 2016, 64, 507-514. [CrossRef]

21. Li, J.; Lepp, A.; Barkley, J.E. Locus of control and cell phone use: Implications for sleep quality, academic performance, and subjective well-being. Comput. Hum. Behav. 2015, 52, 450-457. [CrossRef]

22. Yoon, S.J. Does social capital affect SNS usage? A look at the roles of subjective well-being and social identity. Comput. Hum. Behav. 2014, 41, 295-303. [CrossRef]

23. Li, C.; Shi, X.; Dang, J. Online communication and subjective well-being in Chinese college students: The mediating role of shyness and social self-efficacy. Comput. Hum. Behav. 2014, 34, 89-95. [CrossRef]

24. Atalan, A. Is the lockdown important to prevent the COVID-9 pandemic? Effects on psychology, environment and economyperspective. Ann. Med. Surg. 2020, in press. [CrossRef] [PubMed]

25. Kang, J.; Jang, Y.Y.; Kim, J.; Han, S.H.; Lee, K.R.; Kim, M.; Eom, J.S. South Korea's Reponses to Stop the COVID-19 Pandemic. Am. J. Infect. Control 2020, in press. [CrossRef] [PubMed]

26. Elavarasan, R.M.; Pugazhendhi, R. Restructured society and environment: A review on potential technological strategies to control the COVID-19 pandemic. Sci. Total Environ. 2020, 725, 138858. [CrossRef] [PubMed]

27. Su, L.; Huang, S.S.; Pearce, J. How does destination social responsibility contribute to environmentally responsible behaviour? A destination resident perspective. J. Bus. Res. 2018, 86, 179-189. [CrossRef]

28. He, X.; Hu, D.; Swanson, S.R.; Su, L.; Chen, X. Destination perceptions, relationship quality, and tourist environmentally responsible behavior. Tour. Manag. Perspect. 2018, 28, 93-104. [CrossRef]

29. Lee, T.H. How recreation involvement, place attachment and conservation commitment affect environmentally responsible behavior. J. Sustain. Tour. 2011, 19, 895-915. [CrossRef]

30. Thapa, B. The mediation effect of outdoor recreation participation on environmental attitude-behavior correspondence. J. Environ. Educ. 2010, 41, 133-150. [CrossRef]

31. Nguyen, Q.A.; Hens, L.; Nguyen, N.; MacAlister, C.; Lebel, L. Explaining intentions by Vietnamese schoolchildren to adopt pro-environmental behaviors in response to climate change using theories of persuasive communication. Environ. Manag. 2020, 66, 845-857. [CrossRef] [PubMed]

32. Robinson, S.L.; Morrison, E.W. The development of psychological contract breach and violation: A longitudinal study. J. Organ. Behav. 2000, 21, 525-546. [CrossRef]

33. Malhotra, N.; Sahadev, S.; Purani, K. Psychological contract violation and customer intention to reuse online retailers: Exploring mediating and moderating mechanisms. J. Bus. Res. 2017, 75, 17-28. [CrossRef]

34. Rousseau, D.M.; Tijoriwala, S.A. Assessing psychological contracts: Issues, alternatives and measures. J. Organ. Behav. Int. J. Ind. Occup. Organ. Psychol. Behav. 1998, 19, 679-695. [CrossRef]

35. Theotokis, A.; Pramatari, K.; Tsiros, M. Effects of expiration date-based pricing on brand image perceptions. J. Retail. 2012, 88, 72-87. [CrossRef]

36. Knights, J.A.; Kennedy, B.J. Psychological contract violation: Impacts on job satisfaction and organizational commitment among Australian senior public servants. Appl. HRM Res. 2005, 10, 57-72.

37. Coyle-Shapiro, J.; Kessler, I. The Psychological Contract in the UK Public Sector: Employer and Employee Obligations and Contract Fulfilment. In Academy of Management Proceedings; Academy of Management: Briarcliff Manor, NY, USA, 1998; Volume 1998, pp. A1-A7.

38. Peng, K.Z.; Wong, C.S.; Song, J.L. How do Chinese employees react to psychological contract violation? J. World Bus. 2016, 51, 815-825. [CrossRef]

39. Arasli, H.; Arici, H.E.; Çakmakoğlu Arici, N. Workplace favouritism, psychological contract violation and turnover intention: Moderating roles of authentic leadership and job insecurity climate. Ger. J. Hum. Resour. Manag. 2019, 33, 197-222. [CrossRef]

40. Duran, F.; Bishopp, D.; Woodhams, J. Relationships between psychological contract violation, stress and well-being in firefighters. Int. J. Workplace Health Manag. 2019, 12, 120-133. [CrossRef]

41. Hammer, B.; Zhang, T.; Shadbad, F.N.; Agrawal, R. Psychological Contract Violation and Sharing Intention on Facebook. In Proceedings of the 52nd Hawaii International Conference on System Sciences, Grand Wailea, Maui, HI, USA, 8-11 January 2019.

42. Ha, J.; Park, K.; Park, J. Which restaurant should I choose? Herd behavior in the restaurant industry. J. Foodserv. Bus. Res. 2016, 19, 396-412. [CrossRef]

43. Litimi, H. Herd behavior in the French stock market. Rev. Account. Financ. 2017, 16, 497-515. [CrossRef]

44. Jiang, X.; Du, P. Analysis of homebuyers' conformity behavior based on herd effect. Manag. Eng. 2016, $22,89$.

45. Lin, S.Q. The influence of litter on recreation experience environmental perception approach in Sun-moon Lake. Outdoor Recreat. Res. 1990, 3, 17-30.

46. Cheng, T.-M.; Wu, H.C.; Huang, L.-M. The influence of place attachment on the relationship between destination attractiveness and environmentally responsible behavior for island tourism in Penghu, Taiwan. J. Sustain. Tour. 2013, 21, 1166-1187. [CrossRef] 
47. Hair, J.F.; Black, W.C.; Babin, B.J.; Anderson, R.E. Multivariate Data Analysis: A Global Perspective, 7th ed.; Pearson: Upper Saddle River, NJ, USA, 2010.

48. Kline, R.B. Principles and Practice of Structural Equation Modeling; The Guilford Press: New York, NY, USA, 2011.

49. Podsakoff, P.M.; MacKenzie, S.B.; Lee, J.Y.; Podsakoff, N.P. Common method biases in behavioral research: A critical review of the literature and recommended remedies. J. Appl. Psychol. 2003, 88, 879-903. [CrossRef] [PubMed]

50. Preacher, K.J.; Rucker, D.D.; Hayes, A.F. Addressing moderated mediation hypotheses: Theory, methods, and prescriptions. Multivar. Behav. Res. 2007, 42, 185-227. [CrossRef] [PubMed] 